\title{
Hubungan antara Paparan Asap Rokok dan Pola Makan dengan Kejadian Penyakit Jantung Koroner pada Perempuan Usia Produktif
}

\section{The Correlation of Cigarette Smoke Exposure and Dietary Habit of Coronary Heart Disease in Women of Productive Age}

\author{
Devit Dewi Anggraini ${ }^{* 1}$, Atik Choirul Hidajah $^{1}$
}

\begin{abstract}
ABSTRAK
Latar Belakang: Penyakit tidak menular yang menjadi masalah utama kesehatan masyarakat saat ini salah satunya adalah Penyakit Jantung Koroner (PJK). Gaya hidup dan tingkah laku seseorang memegang peranan penting dalam PJK. Perokok pasif yang terpapar asap rokok secara terusmenerus dalam jangka waktu lama dapat memberi pengaruh negatif pada kesehatan jantung. Makan buah dan sayur merupakan faktor protektif. Artinya, semakin banyak mengonsumsi buah dan sayur maka akan memberikan manfaat sebagai faktor protektif bagi jantung.

Tujuan: penelitian ini bertujuan untuk menganalisis hubungan antara paparan asap rokok dan pola makan dengan kejadian PJK pada perempuan usia produktif yang mendapatkan perawatan ambulatori di RSUD Dr. M. Soewandhie Surabaya.

Metode: penelitian ini merupakan penelitian kasus kontrol. Sample diambil dengan simple random sampling. Jumlah kasus adalah 41 perempuan yang didiagnosa menderita PJK. Rasio kasus dan kontrol adalah $1: 1$. Analisis data menggunakan uji regresi logistik berganda.

Hasil: paparan asap rokok serta konsumsi sayur dan buah berhubungan dengan kejadian PJK pada perempuan usia produktif dengan nilai $p$ berturut-turut sebesar 0,03 dan 0,00 . Perempuan yang terpapar asap rokok dengan kategori berat berisiko 11,78 kali untuk mengalami PJK $(O R=11,78)$, sedangkan yang kurang konsumsi sayur dan buah memiliki risiko 5,03 kali mengalami PJK dibanding yang cukup konsumsi sayur dan buah $(\mathrm{OR}=5,03)$.

Kesimpulan: paparan asap rokok yang berat serta kurang konsumsi sayur dan buah berhubungan dengan kejadian PJK pada perempuan usia produktif di RSUD Dr. M. Soewandhie Surabaya. Berdasarkan hal tersebut, optimalisasi regulasi area bebas rokok sangat dibutuhkan. Dan, perempuan usia produktif perlu banyak mengkonsumsi sayur dan buah.
\end{abstract}

Kata Kunci: faktor risiko, penyakit jantung koroner, perempuan usia produktif 


\begin{abstract}
Background: Non-communicable diseases that become the main problem of public health today is one of them is Coronary Heart Disease (CHD). Lifestyle and behavior of someone plays an important role in CHD. Passive smokers who are exposed to cigarette smoke continuously for a long time can have a negative effect on heart health. Eating fruits and vegetables is a protective factor. That is, the more eating fruits and vegetables it will provide benefits as a protective factor for the heart. Objective: This study aims to analyze the effect of exposure to cigarette smoke and eating patterns on the incidence of CHD in reproductive age females who received ambulatory care at RSUD Dr. M. Soewandhie Surabaya.

Methods: This was a case-control study. Samples were taken by simple random sampling. Number of cases were 41 women who diagnosed as CHD. The ratio of case and control was 1:1. Data analysis used multiple logistic regression test.

Results: exposure to cigarette smoke and diet associated with CHD events in women of reproductive age with $p$ values of 0.03 and 0.00 respectively. Women who were exposed to cigarette smoke with weight category had an 11.78 times risk of developing CHD (OR=11.78), while those with less vegetable and fruit consumption had a risk of 5.03 times having CAD than the consumption of vegetables and fruits (OR=5.03).

Conclusion: severe exposure to tobacco smoke and lack of consumption of vegetables and fruits affect the incidence of CHD in childbearing females in RSUD Dr. M. Soewandhie Surabaya. Based on that, optimalization of non-smoking area regulation is needed. And, the women in productive ages need consume lots of vegetables and fruits.
\end{abstract}

Keywords: risk factors, coronary heart disease, women in productive ages

\author{
*Koresponden: \\ devit.dewi.anggraini-2015@fkm.unair.ac.id \\ ${ }^{1}$ Departemen Epidemiologi \\ Fakultas Kesehatan Masyarakat, Universitas Airlangga
}

\section{PENDAHULUAN}

Penyakit Tidak Menular (PTM) menyebabkan kematian lebih dari 36 juta orang setiap tahun. Sembilan puluh persen kematian tersebut terjadi di negara berpenghasilan rendah dan menengah ${ }^{1}$. Pada tahun 2020, diperkirakan terdapat 44 juta kematian akibat penyakit tidak menular di dunia. Empat besar penyakit yang mengakibatkan kematian tersebut yaitu penyakit jantung koroner sebanyak 17,3 juta orang per tahun, diikuti oleh kanker, penyakit pernafasan, dan diabetes melitus ${ }^{2}$. Penyakit Jantung Koroner (PJK) dan stroke diperkirakan akan menyebabkan kematian yang terus meningkat mencapai 23,3 juta orang pada tahun $2030^{3}$.

Di Indonesia, prevalensi penyakit jantung koroner pada tahun 2013 sebesar $0,5 \%$ atau 883.447 orang yang mana Provinsi Jawa Timur berada di posisi kedua terbanyak di Indonesia. Di Provinsi Jawa Timur, estimasi jumlah penderita penyakit jantung koroner yaitu sebesar $0,5 \%$ atau 144.279 orang $^{3}$.

Surabaya merupakan salah satu kota dengan kasus PJK tertinggi. Selama tiga tahun terakhir jumlah kasus cenderung mengalami peningkatan yaitu 1870 kasus pada tahun 2014, 11644 kasus pada tahun 2015, dan 12412 kasus pada tahun 2016 ${ }^{4}$. Penyakit Jantung Koroner (PJK) juga menyumbang 
prevalensi terbesar penyebab kehilangan produktivitas dan kematian prematur pada usia produktif. Hal ini disebabkan oleh globalisasi dan perkembangan teknologi yang memengaruhi gaya hidup dan aktivitas masyarakat. Pada tahun 2016, jumlah penderita PJK usia produktif (15-64 tahun) di Kota Surabaya cukup besar yaitu $88,21 \%$. Data penemuan kasus PJK pada perempuan juga cenderung mengalami peningkatan selama tiga tahun terakhir yaitu 988 orang pada tahun 2014, 4737 orang pada tahun 2015, dan 5200 orang pada tahun $2016^{5}$.

Menurut data rekam medis, PJK menempati peringkat ketiga dari sepuluh penyakit terbanyak di unit rawat jalan RSUD Dr. M. Soewandhie Surabaya. Data kunjungan pasien PJK mengalami peningkatan pada bulan September-Desember $2016^{6}$.

Penyakit Jantung Koroner (PJK) mempunyai beberapa faktor risiko. Faktor risiko yang tidak dapat dimodifikasi yaitu jenis kelamin, genetik, dan usia. Faktor risiko yang dapat dimodifikasi yaitu perilaku merokok, hipertensi, dislipidemia, obesitas, kurang aktivitas fisik, stress, diabetes mellitus, kebiasaan diet yang kurang baik dan konsumsi alkohol ${ }^{7}$.

Menurut Saesarwati (2016) tingkah laku dan gaya hidup seseorang memegang peranan penting dalam $\mathrm{PJK}^{8}$. Perokok pasif yang dalam jangka waktu lama terpapar asap rokok secara terus-menerus dapat memberi pengaruh negatif pada kesehatan jantung ${ }^{9}$. Di Kabupaten Gunungkidul, makan sayur dan buah juga memiliki hubungan yang signifikan dengan $\mathrm{PJK}^{10}$. Makan buah dan sayur merupakan faktor protektif. Artinya, semakin banyak mengonsumsi buah dan sayur maka akan memberikan manfaat sebagai faktor protektif bagi jantung.

Penelitian yang dilakukan oleh Martini dan Sulistyowati (2005) tentang perilaku merokok diantara para remaja di Jawa Timur menyatakan bahwa $70 \%$ dari semua perokok adalah remaja yang berusia 17 tahun atau lebih muda. Usia perokok yang lebih muda memungkinkan untuk memberikan paparan asap rokok lebih besar kepada lingkungan sekitarnya ${ }^{11}$.
Berdasarkan Survei Diet Total tahun 2014, konsumsi sayur dan buah di Provinsi Jawa Timur tergolong masih rendah yaitu sebesar 53,8 gram/orang/hari. Hal ini sangat jauh dari anjuran WHO untuk mengkonsumsi sayur dan buah sebesar 400 gram/orang/hari. Di kota Surabaya, rerata konsumsi buah juga masih sangat rendah yaitu sebesar 0,7 porsi/orang/hari dan sayuran sebesar 1,2 porsi/orang/hari. Padahal pedoman gizi seimbang menganjurkan konsumsi sayur sebanyak 3-4 porsi dan buah 2-3 porsi ${ }^{1}$.

Mempertimbangkan tingginya kasus PJK, perilaku merokok, pola makan tidak sehat dan akibat yang dapat ditimbulkan maka perlu dilakukan penelitian tentang analisis hubungan antara paparan asap rokok dan pola makan dengan kejadian PJK pada perempuan usia produktif di Kota Surabaya.

\section{METODE}

Penelitian ini menggunakan metode observasional dengan desain kasus kontrol (case control). Penelitian dilakukan di RSUD Dr. Mohammad Soewandhie Surabaya dengan waktu pengumpulan data yaitu NovemberDesember 2017. Populasi kasus dalam penelitian ini adalah semua pasien perempuan usia produktif (15 - 64 tahun) penderita PJK yang berkunjung pada bulan November 2017 menurut data rekam medis di poliklinik jantung RSUD Dr. M. Soewandhie Surabaya sebanyak 215 orang. Populasi kontrol adalah semua pasien perempuan usia produktif (15 64 tahun) bukan penderita PJK yang berkunjung pada bulan November 2017 menurut data rekam medis di poliklinik gigi RSUD Dr. M. Soewandhie Surabaya sebanyak 531 orang. Besar sampel yaitu 41 orang pada populasi kasus dan 41 orang pada populasi kontrol ditentukan menggunakan rumus Murti dengan metode simple random sampling.

Penelitian ini telah mendapat persetujuan dari Komite Etik Fakultas Kesehatan Masyarakat Universitas Airlangga dengan nomor 573-KEPK. Data paparan asap rokok didapatkan dengan cara wawancara menggunakan kuesioner yang diadaptasi dari penelitian Rosmiatin (2012) yang berjudul Analisis Faktor Risiko terhadap Kejadian 
Penyakit Jantung Koroner pada Wanita Usia Lanjut Usia di RSUPN Dr. Cipto Mangunkusumo Jakarta. Paparan asap rokok dikategorikan menjadi berat apabila jumlah perokok aktif disekitarnya $>3$ orang dan lama terpapar asap rokok $>15$ menit/hari, sedang apabila jumlah perokok aktif disekitarnya $>3$ orang dan lama terpapar asap rokok $\leq 15$ menit/hari atau jumlah perokok aktif disekitarnya 1-3 orang dan lama terpapar asap rokok $>15$ menit/hari, ringan apabila jumlah perokok aktif disekitarnya 1-3 orang dan lama terpapar asap rokok $\leq 15 \mathrm{menit} / \mathrm{hari}$. Data pola makan diperoleh dengan cara wawancara tentang konsumsi sayur dan buah menggunakan kuisioner Food Frequency dan Food Recall 2×24 jam. Status PJK dan bukan
PJK dapat diketahui melalui data rekam medis RSUD Dr. M. Soewandhie Surabaya. Analisis data menggunakan uji regresi logistik untuk menganalisis hubungan antara paparan asap rokok dan pola makan dengan kejadian PJK pada perempuan usia produktif di Kota Surabaya.

\section{HASIL DAN PEMBAHASAN}

Tabel 1 menunjukkan bahwa pasien PJK pada perempuan usia produktif yang menjadi sampel penelitian sebagian besar memiliki usia 51-60 tahun yaitu sebanyak 19 orang (46,34\%). Sedangkan pasien non PJK sebagian besar memiliki usia 41-50 tahun yaitu sebanyak 13 orang $(31,71 \%)$.

Tabel 1. Distribusi Responden Berdasarkan Umur

\begin{tabular}{ccccc}
\hline \multirow{2}{*}{ Umur Responden (Tahun) } & \multicolumn{2}{c}{ PJK } & \multicolumn{2}{c}{ Tidak PJK } \\
\cline { 2 - 5 } & $\mathbf{n}$ & $\mathbf{\%}$ & $\mathbf{n}$ & $\mathbf{\%}$ \\
\hline $21-30$ & 1 & 2,44 & 9 & 21,95 \\
$31-40$ & 3 & 7,32 & 8 & 19,51 \\
$41-50$ & 11 & 26,83 & 13 & 31,71 \\
$51-60$ & 19 & 46,34 & 6 & 14,64 \\
$61-70$ & 7 & 17,07 & 5 & 12,19 \\
\hline Total & 41 & 100,00 & 41 & 100,00 \\
\hline
\end{tabular}

Tabel 2. Distribusi Responden Berdasarkan Status Pekerjaan

\begin{tabular}{|c|c|c|c|c|}
\hline \multirow{2}{*}{ Status Pekerjaan } & \multicolumn{2}{|c|}{ PJK } & \multicolumn{2}{|c|}{ Tidak PJK } \\
\hline & $\mathbf{n}$ & $\%$ & $\mathbf{n}$ & $\%$ \\
\hline Tidak Bekerja & 31 & 75,61 & 17 & 41,46 \\
\hline Bekerja & 10 & 24,39 & 24 & 58,54 \\
\hline Total & 41 & 100,00 & 41 & 100,00 \\
\hline
\end{tabular}

Tabel 3. Distribusi Responden Berdasarkan Tingkat Pendidikan

\begin{tabular}{lcccc}
\hline \multirow{2}{*}{ Tingkat Pendidikan } & \multicolumn{2}{c}{ PJK } & \multicolumn{2}{c}{ Tidak PJK } \\
\cline { 2 - 5 } & $\mathbf{n}$ & $\mathbf{0}$ & $\mathbf{n}$ & $\%$ \\
\hline Tidak Sekolah & 3 & 7,32 & 1 & 2,44 \\
Tidak Tamat SD & 5 & 12,20 & 3 & 7,32 \\
Tamat SD & 16 & 39,02 & 14 & 34,15 \\
Tidak Tamat SMP & 0 & 0 & 0 & 0 \\
Tamat SMP & 9 & 21,95 & 7 & 17,07 \\
Tidak Tamat SMA & 0 & 0 & 0 & 0 \\
Tamat SMA & 7 & 17,07 & 16 & 39,02 \\
Perguruan Tinggi & 1 & 2,44 & 0 & 0 \\
\hline \multicolumn{1}{c}{ Total } & 41 & 100,00 & 41 & 100,00 \\
\hline \multicolumn{1}{c}{} & & &
\end{tabular}


Tabel 4. Pengaruh Paparan Asap Rokok terhadap Kejadian Penyakit Jantung Koroner pada Perempuan Usia Produktif

\begin{tabular}{lccccc}
\hline \multirow{2}{*}{ Paparan Asap Rokok } & \multicolumn{2}{c}{ PJK } & \multicolumn{2}{c}{ Tidak PJK } & \multirow{2}{*}{$\boldsymbol{p}$ value } \\
\cline { 2 - 5 } & $\mathbf{n}$ & $\mathbf{\%}$ & $\mathbf{n}$ & $\mathbf{\%}$ & \\
\hline Berat & 7 & 17,08 & 2 & 4,88 & 0,03 \\
Sedang & 26 & 63,41 & 26 & 63,41 & 0,36 \\
Ringan (Reference group) & 8 & 19,51 & 13 & 31,71 & - \\
\hline \multicolumn{1}{c}{ Total } & 41 & 100,00 & 41 & 100,00 & \\
\hline
\end{tabular}

Tabel 5. Distribusi Responden Berdasarkan Konsumsi Sayur dan Buah

\begin{tabular}{lcccccc}
\hline \multirow{2}{*}{ Konsumsi Sayur dan Buah } & \multicolumn{2}{c}{ PJK } & \multicolumn{2}{c}{ Tidak PJK } & \multirow{2}{*}{$\boldsymbol{p}$ value } \\
\cline { 2 - 6 } & $\mathbf{n}$ & $\mathbf{\%}$ & $\mathbf{n}$ & $\mathbf{\%}$ & \\
\hline Kurang & 26 & 63,41 & 11 & 26,83 & 0,00 \\
Cukup & 15 & 36,59 & 30 & 73,17 & \\
\hline \multicolumn{2}{c}{ Total } & 41 & 100,00 & 41 & 100,00 & \\
\hline
\end{tabular}

Tabel 2 menunjukkan bahwa sebagian besar pasien PJK tidak bekerja yaitu sebanyak 31 orang $(75,61 \%)$. Sedangkan pasien non PJK sebagian besar bekerja yaitu sebanyak 24 orang $(58,54 \%)$.

Tabel 3 menunjukkan bahwa pasien PJK pada perempuan usia produktif sebagian besar memiliki tingkat pendidikan Sekolah Dasar (SD). Sedangkan pasien non PJK sebagian besar memiliki tingkat pendidikan Sekolah Menengah Atas (SMA).

Tabel 4 menunjukkan bahwa sebagian besar pasien PJK dan non PJK pada perempuan usia produktif yang menjadi sampel penelitian mengalami paparan asap rokok yang sedang. Hasil uji statistik memberikan informasi bahwa paparan asap rokok yang berat berhubungan dengan kejadian PJK pada perempuan usia produktif di RSUD Dr. M. Soewandhie Surabaya. Hasil uji statistik membuktikan dengan nilai $p$-value sebesar 0,03 $(p<0,05)$.

Tabel 5 menunjukkan bahwa pasien PJK pada perempuan usia produktif sebagian besar kurang mengkonsumsi sayur dan buah. Sedangkan pasien non PJK sebagian besar cukup mengkonsumsi sayur dan buah. Hasil uji statistik memberikan informasi bahwa kurang konsumsi sayur dan buah berhubungan dengan kejadian PJK pada perempuan usia produktif di RSUD Dr. M. Soewandhie Surabaya. Hal ini dibuktikan dari hasil uji statistik dengan $p$-value sebesar $0,00(p<0,05)$.
Distribusi responden menunjukkan bahwa pasien PJK pada perempuan usia produktif sebagian besar memiliki usia 51-60 tahun. Umur merupakan karakteristik individu yang tidak dapat diubah. Penambahan usia akan meningkatkan risiko terjadinya PJK. Penurunan fisiologi tubuh dan fungsi anatomi termasuk pembuluh darah dan organ jantung dapat meningkatkan kerentanan terhadap ateroskerotik koroner ${ }^{12}$. Lemak dan kolesterol yang menempel di dinding pembuluh darah menimbulkan endapan sehingga mengganggu aliran darah yang melewatinya ${ }^{13}$.

Distribusi responden menunjukkan bahwa sebagian besar pasien PJK tidak bekerja. Hasil riset yang diperoleh Salim (2013) menyatakan bahwa prevalensi PJK sebagian besar terjadi pada responden yang tidak bekerja. Sedangkan responden penderita non PJK sebagian besar memiliki pekerjaan ${ }^{14}$. Aktivitas fisik dapat dikatakan apabila seseorang sedang bekerja, bahkan melakukan pekerjaan dapat mencukupi sekitar 30\% dari total kebutuhan aktivitas fisik. Tingginya kebutuhan energi yang diperlukan dalam melakukan pekerjaan dan kemungkinan munculnya stress akibat beban kerja menjadi hal yang perlu dipertimbangkan ${ }^{15}$.

Distribusi responden menunjukkan bahwa pasien PJK pada perempuan usia produktif sebagian besar memiliki tingkat pendidikan Sekolah Dasar (SD). Tingkat pengetahuan seseorang terhadap PJK dapat dipengaruhi oleh faktor pendidikan. Sehingga 
semakin tinggi tingkat pendidikan responden maka pengetahuan responden tentang PJK semakin banyak sehingga bisa melakukan tindakan pencegahan terhadap PJK ${ }^{16}$.

Hasil uji statistik memberikan informasi bahwa paparan asap rokok yang berat berhubungan dengan kejadian PJK pada perempuan usia produktif di RSUD Dr. M. Soewandhie Surabaya. Supriyono (2008) menyatakan bahwa perokok pasif meningkatkan risiko sebesar 20-30\% menderita PJK dibandingkan dengan orang yang tidak kontak langsung dengan perokok aktif. Akibat buruk rokok bukan hanya pada perokok aktif, tetapi juga bagi perokok pasif. Asap rokok yang dihirup oleh perokok pasif mengandung 2 kali lipat racun dibandingkan dengan yang dihirup oleh perokok aktif. Selain itu, asap rokok yang dikeluarkan oleh perokok aktif mengandung nikotin dan tar lebih banyak daripada yang dihirup oleh perokok aktif ${ }^{17}$.

Dinding pembuluh darah dapat dirusak oleh pembuluh darah. Asap rokok yang mengandung nikotin akan merangsang hormon adrenalin yang mengakibatkan metabolisme lemak berubah sehingga kandungan High Density Lipoprotein (HDL) menurun. Adrenalin disamping menyempitkan pembuluh darah dan merangsang kerja jantung, juga menyebabkan terjadinya penggumpalan trombosit sehingga semua proses penyempitan akan terjadi. Jadi penyakit jantung koroner dapat disebabkan oleh asap rokok yang tampak sederhana. Selain itu nikotin yang terkandung dalam asap rokok bisa menyebabkan peningkatan hormon adrenalin, yang bersifat memacu jantung dan meningkatkan tekanan darah. Jantung akan bekerja keras, sedangkan tekanan darah akan semakin meninggi, dan berakibat timbulnya hipertensi ${ }^{18}$.

Menurut Goniewicz (2010), orang yang merokok lebih dari 20 batang atau lebih dalam sehari memiliki risiko dua hingga tiga kali lebih tinggi mengalami PJK daripada populasi umum. Menurut studi Framingham, merokok $>30$ batang/hari mempunyai 3-5 kali risiko terkena PJK, sedangkan merokok $>40$ batang/hari mempunyai 6,5 kali risiko terkena PJK $^{19}$.
Zat yang terkandung dalam rokok selain nikotin adalah zat karbon monoksida (CO). Sama halnya dengan nikotin, CO juga berada di aliran darah selama 24 jam sejak rokok dihisap. Saat berada dalam tubuh, CO akan masuk dalam aliran darah dan mengikat oksigen yang dibawa oleh sel darah merah. Pengikatan $\mathrm{CO}$ dengan oksigen menyebabkan sel darah merah tidak lagi membawa oksigen yang cukup untuk disalurkan kepada jaringan lain. Ketika tidak mendapatkan oksigen yang cukup, maka jaringan tersebut akan mati. Seseorang dengan keadaan seperti ini akan merasakan napas yang pendek dan denyut nadi yang lebih cepat sebagai dampak dari pengikatan CO dengan oksigen ${ }^{20}$.

Hasil uji statistik memberikan informasi bahwa kurang konsumsi sayur dan buah berhubungan dengan kejadian PJK pada perempuan usia produktif di RSUD Dr. M. Soewandhie Surabaya. Serat memiliki fungsi salah satunya yaitu sebagai penghambat absorbsi lemak dan secara tidak langsung dapat menurunkan kadar kolesterol ${ }^{21}$. Makan buah dan sayur memiliki hubungan yang signifikan dengan PJK di Kabupaten Gunungkidul. Makan buah dan sayur merupakan faktor protektif. Artinya, semakin banyak mengkonsumsi buah dan sayur maka akan memberikan manfaat sebagai faktor protektif bagi jantung. Analisis terhadap 10 studi epidemiologis tentang hubungan antara asupan serat dengan risiko PJK, serta 67 penelitian klinis mengenai pengaruh konsumsi serat terhadap pengurangan kadar kolesterol darah menyimpulkan bahwa asupan serat dapat menurunkan level kolesterol sehingga mencegah terjadinya $\mathrm{PJK}^{22}$.

\section{KESIMPULAN}

Paparan asap rokok yang berat serta
kurang konsumsi sayur dan buah berhubungan dengan kejadian PJK pada perempuan usia produktif di RSUD Dr. M. Soewandhie Surabaya. Disarankan untuk penelitian selanjutnya dapat melaksanakan penelitian dengan variabel yang lain selain variabel pada penelitian dan dengan jumlah sampel yang lebih besar untuk mendapatkan hasil analisis yang lebih baik. 


\section{ACKNOWLEDGMENT}

Peneliti mengucapkan terimakasih kepada RSUD Dr. M. Soewandhie Surabaya yang telah memberikan izin penelitian sehingga dapat terlaksana dengan baik, ibu ibu yang telah menjadi responden, serta teman - teman yang telah banyak membantu dalam penelitian ini.

\section{REFERENSI}

1. Indonesia, K. K. R. Info Datin: Situasi Kesehatan Jantung. (2014).

2. World Organization. World Heart Federation. World Stroke Organization. Global Atlas on Cardiovascular disease prevention and control. Glob. atlas Cardiovasc. Dis. Prev. Control. 155 (2011). doi:NLM classification: WG 120

3. Badan Penelitian dan Pengembangan Kesehatan. Riset Kesehatan Dasar (RISKESDAS) 2013. Lap. Nas. 2013 1-384 (2013). doi:1 Desember 2013

4. Surabaya, D. K. K. Laporan Tahunan Dinas Kesehatan Kota Surabaya Tahun 2016. (2016).

5. Who, W. H. O. World Health Statistics. WHO World Health Organization 27, (2012).

6. RSUD Dr. M. Soewandhie Surabaya. Laporan Rekam Medis Penyakit Jantung Koroner. (2016).

7. American Heart Association. Health Care Research: Coronary Heart Disease. (2015).

8. Saesarwati, D., Satyabakti, P., Epidemiologi, D., Kesehatan, F. \& Universitas, M. Analysis of Modifiable Risk Factors Coronary Heart Disease in. J. Promkes 4, 22-33 (2016).

9. Bustan, M. . Epidemiologi Penyakit Tidak Menular. 2nd ed. (Rineka Cipta, 2007).

10. Wakasala, M. Prevalensi Faktor Risiko Pada Orang Dewasa yang Memiliki Gejala Subjektif ke Arah Penyakit Jantung Koroner di Kabupaten GunungKidul Tahun 2015. (Universitas Gadjah Mada, 2016).

11. Martini, S. dan Sulistyowati, M. The Determinants of Smoking Behavior among Teenagers in East Java Province, Indonesia. HNP Discuss. Pap. Econ. Tob. Control Pap. 32 (2005).

12. Dayu, M. S. T. Hubungan Riwayat Lama Merokok dengan Angka Kejadian Penyakit Jantung Koroner di RSUD Dr. H. Abdul Moeloek Provinsi Lampung Tahun 2015. 1-10 (2015).

13. Zahrawardani, D., Herlambang, K. S. \& Anggraheny, H. D. Analisis Faktor Risiko Kejadian Penyakit Jantung Koroner di RSUP Dr Kariadi Semarang. J. Kedokt. Muhammadiyah 1, 13 (2013).

14. Salim, A. Y. \& Nurrohmah, A. Hubungan Olahraga Dengan Kejadian Penyakit Jantung Koroner Di RSUD Dr. Moewardi. Gaster 10, 48-56 (2013).

15. Kalalembang, A. Faktor-faktor yang Berhubungan dengan Kejadian Penyakit Jantung Koroner di RSU Kanujoso Djatiwibowo Balikapapan. (Universitas Airlangga, 2003).

16. Setiani, R. Faktor Risiko yang Berhubungan dengan Kejadian Penyakit Jantung Koroner pada Kelompok Usia Produktif $\quad(<55$ Tahun). (Universitas Airlangga, 2009).

17. Supriyono, M. Faktor-faktor Risiko yang Berpengaruh Terhadap Kejadian Penyakit Jantung Koroner Pada Kelompok Usia < 45 Tahun. (Universitas Diponegoro, 2008).

18. Corwin, J. Buku Saku Patofisiologi. (EGC Penerbit Buku Kedokteran, 2009).

19. Goniewicz, M. L. et al. Exposure to carbon monoxide from second-hand tobacco smoke in Polish pubs. Cent. Eur. J. Public Health 17, 220-222 (2009).

20. Health, A. on S. and. Smoking, The Heart and Circulation. (2013).

21. Sulastri, D. \& Rahayuningsih, S. Pola Asupan Lemak, Serat, dan Antioksidan, serta Hubungannya dengan Profil Lipid pada Laki-laki Etnik Minangkabau. Maj Kedokt Indon 55, 61-66 (2005).

22. Putri, M. . Analisis Kebiasaan Makan, Riwayat Asupan SAFA, MUFA, PUFA, dan Serat pada Pasien Penyakit Jantung Koroner. (Universitas Airlangga, 2016). 